\title{
ACCOUNTING AND AUDITING
}

DOI: 10.46340/eujem.2021.7.3.4

Daryna Pohribniak

ORCID ID: https://orcid.org/0000-0002-1113-1968

Simon Kuznets Kharkiv National University of Economics

FORMATION OF THE ADAPTIVE MANAGEMENT

FRAMEWORK IN THE SYSTEM

OF ACCOUNTING AND ANALYTICAL SUPPORT

IN ENTERPRISES ASSOCIATIONS

The article considers the issues of adaptive management in the system of accounting and analytical support of business associations. In particular, the formation of adaptive management framework is proposed. The unstable economic environment encourages changes in the activities of economic entities, including their accounting practices. This causes the transformation of their accounting and analytical support. It is necessary to provide accounting information to the management system. The results of comparison of basic management types as a system are proposed according to such criteria as openness, emergence, structure, dynamism, proactivity, subordination, hierarchy. The expediency of using adaptive management in the activities of business associations in the unstable economic environment is substantiated. The organization of accounting features in adaptive management are characterized. The influence of adaptation strategies is substantiated (strategy of active survival, strategy of passive survival, strategy of active influence on the external environment) within the framework of adaptive management in the sphere of accounting. The relation of adaptation strategies to accounting orientation is provided. The characteristics of "adaptability" and "flexibility" are outlined, and their influence on the decision of the management of the enterprises association subject is substantiated concerning the possibility and / or expediency of the introduction / improvement of adaptive management. The generalized adaptive management framework of enterprises association is offered (considering the adapter as a management tool and the enterprise activities and integration restrictions as a management object). Hierarchies of adapters have been developed for mergers of enterprises with a contractual form and with the organization of a joint venture. The adapter is defined as a tool related to "indicator-management decision". It is necessary for managerial influence in the activities of enterprises association. The main tasks of adapters are characterized for the first (enterprise-external environment), second (enterprise-enterprise) and third (enterprise-external environment) levels.

Keywords: organization of accounting, accounting information, accounting and analytical support, management accounting, adaptive management, adaptive management framework.

Introduction. The dynamism and unpredictability of the economic environment requires businesses to use new approaches to the organization of their activities. This applies to both foreign and domestic policy of enterprises: reaching a new level in the search for business partners, the active use of social networks in marketing strategy, creating and maintaining the image of the enterprise. Therefore, in the current conditions of unpredictability and instability of the economic environment, it is proposed to focus on the adaptive management of business associations to avoid the above difficulties in the activities.

The aim of this study is to substantiate the theoretical aspects and develop practical recommendations for the formation of the adaptive management framework in the system of accounting and analytical support for business associations.

Analysis of latest publications. Adaptive control is the subject of research in many works of such scientists as Aubakirova H., Borysov A., Demianenko T., Druker P., Yelnykova H., Ziablytskaia N., Karpov L., Maksymova L., Maslodudov Yu., Myronova N., Miasnykov V., Stasiuk V., Tiukin I., Kharytonova A., 
Khaustova I., Yanchenko N. and others. However, within the accounting and analytical support of business associations, the issue of forming adaptive management framework remains under discussion.

Research Results. There is no consensus on the definition of "adaptive management" today, so it is worth highlighting its key characteristics: focusing on the conditions of unpredictability and variability of the environment, the availability of incomplete information for management decisions, emphasis on the need for flexibility and adaptability implementation of new management decisions in the activities of the business entity in accordance with the current situation, which have not been taken before.

Considering the mentioned above characteristics of adaptive control, the following comparison of management types regarding system approach is proposed (Table 1). Chalyi S. and Levykin I. outline the following main types of management: open management, feedback management and adaptive management ${ }^{1}$.

Chalyi S. and Levykin I. believe that in modern practice open management is almost non-existent, as its feature is "... a priori given algorithm of behavior of the object managed" ${ }^{2}$, the implementation of which is almost impossible in the current economic conditions.

Table 1

Comparison of basic types of management as a system

\begin{tabular}{|c|c|c|c|}
\hline $\begin{array}{c}\text { System } \\
\text { characteristics / } \\
\text { Type of } \\
\text { management }\end{array}$ & Open management & Feedback management & Adaptive management \\
\hline $\begin{array}{l}\text { Separating from } \\
\text { the environment }\end{array}$ & \multicolumn{3}{|c|}{ The presence of existence limits } \\
\hline Openness & $\begin{array}{l}\text { The influence } \\
\text { of the external } \\
\text { environment is not taken } \\
\text { into account }\end{array}$ & $\begin{array}{l}\text { Changing managerial } \\
\text { influences depending on } \\
\text { the amount managed }\end{array}$ & $\begin{array}{l}\text { Ongoing process } \\
\text { of environmental monitoring, } \\
\text { based on the results of which } \\
\text { coordination is carried out in } \\
\text { the process of functioning of } \\
\text { the management system }\end{array}$ \\
\hline Emergence & Missing & $\begin{array}{l}\text { Improved management } \\
\text { through the use of feedback } \\
\text { to change managerial } \\
\text { effects depending on the } \\
\text { results obtained }\end{array}$ & $\begin{array}{l}\text { Ability to predict and adjust } \\
\text { the results of current } \\
\text { management based on the use } \\
\text { of the model of the object } \\
\text { managed }\end{array}$ \\
\hline Structuring & $\begin{array}{l}\text { A structure with } \\
\text { well-defined elements } \\
\text { and connections } \\
\text { between them }\end{array}$ & $\begin{array}{l}\text { The structure, the elements } \\
\text { of which and the } \\
\text { relationships between them } \\
\text { change depending on the } \\
\text { management influences }\end{array}$ & $\begin{array}{l}\text { The structure, the feature } \\
\text { of which is the maximum } \\
\text { efficiency in adjusting the } \\
\text { elements and connections } \\
\text { between them to maintain } \\
\text { the required level of system } \\
\text { adaptability }\end{array}$ \\
\hline Dynamics & $\begin{array}{l}\text { Use the specified } \\
\text { algorithm of behavior } \\
\text { of the object managed }\end{array}$ & $\begin{array}{l}\text { Use a specified algorithm } \\
\text { for the behavior of the } \\
\text { object managed, which } \\
\text { varies with feedback }\end{array}$ & $\begin{array}{l}\text { Ability to change over time } \\
\text { depending on the influence } \\
\text { of endogenous and exogenous } \\
\text { factors }\end{array}$ \\
\hline Proactivity & Missing & Limited opportunity & Complete \\
\hline Subordination & \multicolumn{3}{|c|}{$\begin{array}{l}\text { Existence of the purpose of creation and existence of system depending on the purposes } \\
\text { on which management is focused }\end{array}$} \\
\hline Hierarchy & \multicolumn{3}{|c|}{ Existing subsystems within management have a certain subordination to each other } \\
\hline
\end{tabular}

Source: designed by the author

\footnotetext{
${ }^{1}$ Чалий, С. С., Левикін, І. В. (2016). Метод адаптивного процесного управління на основі прецедентного підходу. Наукоємні технології, 4 (32), 410-413.

${ }^{2}$ Ibid.
} 
Current trends require that business associations should not only improve their financial condition by optimizing and rationalizing the use of resources, but also focus on new approaches to management. Given that the adaptive management of business associations has certain features highlighted in the work of Otenko V. I. ${ }^{1}$, it is proposed to take into account these principles for the accounting organization:

- the need to expand the formation principles of accounting and analytical support in the adaptive management of enterprises associations;

- establishing certain requirements for the accounting organization, which should provide timely information needs of users in order to make management decisions, taking into account the experience gained;

- determining the formation directions of accessible and clear accounting and analytical support in order to provide the necessary information to determine the direction of development and confirm the results not only for management but also for employees of the enterprise;

- development of measures to implement control over the planning and use of resources to improve human resources potential of the entity.

Adaptive management is formed using the appropriate adaptation strategies proposed in the work of Oliinyk T. $\mathrm{V}^{2}$. Thus, different strategies determine a certain direction of management decisions, each one is based on certain information and focused on different users.

Therefore, depending on the adaptation strategy, it is proposed to identify the direction of accounting. The strategy of active survival is characterized by the formation of accounting and analytical support aimed at consolidating information about available resources, finding reserves for enterprise development by optimizing and streamlining the management of labor, financial, production resources, taking into account the influence of external factors.

Passive survival strategies are most common in the practice of large enterprises that operate in stable conditions. Taking into account that in Ukraine such entities include enterprises of various industries, over volatile economic environment creates significant obstacles to their activities. Accounting is provided retrospectively with the determination of compliance to the planned tasks and works actually performed.

Strategies of active influence on the external environment have a completely different vector of orientation, in contrast to the above strategies, which are aimed at the environment of the enterprise itself. Such strategies are used to create favorable economic conditions depending on the goals of enterprises. One of the ways is to create associations of enterprises, the activities of which allow to combine and coordinate the functioning of individual enterprises to achieve common interests through a combination of production capacity, labor and financial potential.

To determine the possibility and / or feasibility of implementing / improving adaptive management in the activities of business associations, it is proposed to take into account the adaptability of business associations. Demianenko T.I. defines "adaptability" as "readiness for stability and flexibility to change one's own style and approach to work in order to achieve specific tasks, as well as to interact effectively at different levels of the economy"3. The researcher emphasizes that "the determining factor in the formation of the competitiveness of the enterprise is the adaptive flexibility of the enterprise based on the application of appropriate strategies to adapt the enterprise to change and achieve competitive goals based on this" ${ }^{4}$. In her work she claims the concept of "adaptability" as "... readiness for stability and flexibility to change their own style and approach to work in order to achieve specific goals, as well as effectively interact at different levels of the economy"5.

Demianenko T. confirms her conclusions by the opinion of such foreign scholars as Senge P., who considered flexibility as a property of the organization to quickly change the organizational structure, activities, etc. ${ }^{6}$ and Stivenson V., who defined flexibility as the ability to adapt to changes in demand for the product and considered it the basis of the competitiveness of the enterprise ${ }^{7}$.

Strokovych H. believes that "the adaptability of the enterprise is the speed of response of the enterprise to changes that occur both in the external and internal environment during operation at all stages of the life

\footnotetext{
${ }^{1}$ Отенко, В. І. (2010). Стратегічний вибір підприємства та його реалізація. Харків: ІНЖЕК, 336.

${ }^{2}$ Олійник, Т. В. (2014). Адаптивні стратегії фінансового управління на підприємстві. Бізнесінформ, 10, 255-259.

3 Дем'яненко, Т. І. (2012). Оцінка рівня адаптивної гнучкості у формуванні адаптивного управління інноваційно-інвестиційним розвитком підприємства. БізнесІнформ, 12, 218.

${ }^{4}$ Ibid.

${ }^{5}$ Ibid.

${ }^{6}$ Сенге, П. (1999). Пятая дисциплина: Искусство и практика самообучающейся организации. Москва:

Олимпбизнес, 448.

${ }^{7}$ Стивенсон, В. Дж. (2002). Управление производством. Москва: Бином; Лаборатория Базовых Знаний, 928.
} 
cycle", so "the overall assessment of the adaptability of the enterprise should include such aspects, as organizational, labor, investment, innovation, production, financial, natural, legislative, informational and infrastructural, characterized by certain groups of indicators $\gg{ }^{1}$.

In the work of Zub A. T. and Laktionov M. V. ${ }^{2}$ it is substantiated that the easiest way to provide an objective assessment of the adaptability of the business entity is possible on the basis of growth rates: production, sales of products, goods, services, market demand, capacity, etc. It is advisable to analyze these indicators in the context of trends that are inherent in the economy as a whole. On the basis of such analysis it is possible to conclude as for the prospects of enterprise development.

The adaptability of enterprises is facilitated by such organizational means as: partial investments, cooperation, franchising, royalties, a set of joint actions, transactions between firms coordinated through the price mechanism, etc ${ }^{3}$. Various forms of integration and mergers of enterprises can help increase their level of adaptability by implementing common strategic goals, forming competitive advantages through access to large capital, which allows to introduce new technologies, ensure synergy of technological and creative resources, etc., and reduce the level adaptability due to the increase in the scale of activity, so it is necessary to take into account what exactly is the adaptation of such an entity.

Chaika T. believes that the system of adaptive management consists of a managed object (MO) and a managing tool (MT) ${ }^{4}$. In this study, it is proposed to consider the managing tool as an adapter, and the managed object as the activities of the enterprise and integration limits (Fig. 1).

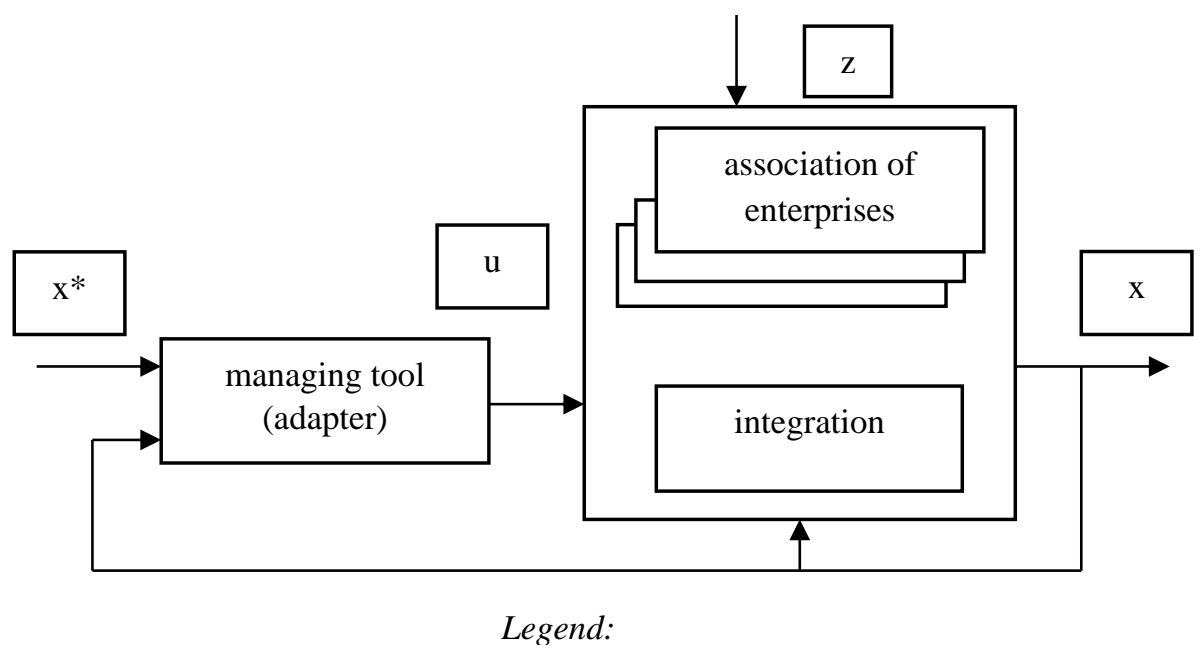

$\mathrm{x}^{*}$ - the desired state of the managed object;

$\mathrm{x}$ - the actual condition of the managed object;

$\mathrm{u}-$ managerial effects that are produced by the adapter;

$\mathrm{z}$ - effects that deviate the object from the desired state;

$\mathrm{x}$ - the actual state of the object.

Fig. 1. Generalized view of the adaptive management framework of business associations

Source: designed by the author based on $^{5}$

\footnotetext{
${ }^{1}$ Строкович, Г. В. (2013). Адаптивність як основа довгострокового функціонування підприємства Вчені записки Харківського гуманітарного університету, 19, 347-354.

<http://dspace.nua.kharkov.ua/jspui/bitstream/123456789/368/1/\%D0\%A1\%D1\%82\%D1\%80\%D0\%BE\%D0\%BA\% D0\%BE\%D0\%B2\%D0\%B8\%D1\%87\%20\%D0\%93.\%D0\%92..pdf> (2021, лютий, 16).

2 Зуб, А. Т., Лактионов, М. В. (2001). Системный стратегический менеджмент: методология и практика.

Москва: Генезис, 752.

${ }^{3}$ Олійник, Т. В. (2014). Адаптивні стратегії фінансового управління на підприємстві. БізнесІнформ, 10, $255-259$.

4 Чайка, Т. Ю. (2015). Адаптивне управління невизначеністю при прийнятті управлінських рішень.

Бізнеслнформ, 2, 283-288.

5 Чайка, Т. Ю. (2015). Адаптивне управління невизначеністю при прийнятті управлінських рішень.

БізнесІнформ, 2, 286; Пилипенко, А. А., Литвиненко, А. О. (2016). Потенціал розвитку матеріально-технічної бази підприємства: ідентифікація та оцінювання. Економічний часопис-XXI, 5-6, 52-57.

<http://soskin.info/userfiles/file/EconomicAnnals-pdf/DOI/ea-V159-11.pdf> (2021, лютий, 16).
} 
According to fig. 1 the state of the managed object is determined by the initial variables (x), which reflect the characteristics from the standpoint of its financial and economic activities. Various influences (z) contribute to the deviation of the actual state (y) from the "desired" ( $\left.x^{*}\right)$. Given the information about the real $(\mathrm{x})$ and "desired" $\left(\mathrm{x}^{*}\right)$ state of the managed object, the managing tool (adapter) produces managerial effects (u). The adapter has a clear interpretation only in the technical context, and in general its purpose is to monitor a specific object and generate managerial signals based on it. Given the specifics of the subject of research, in the organization of accounting and management, it is proposed to define the adapter as a tool, which is determined by the relationship "indicator-management decision" in the accounting: the indicator is formed on the basis of accounting and analytical information and project management, and the decision is made on the basis of interpretation of this indicator. In this study, the focus is mainly on the indicator and the development of information basis for further managerial decisions. Since different types of business associations will be characterized by the corresponding specifics of adaptive management, it is reasonable to develop a hierarchy of adapters - a certain subordination of managing tools in the management system, which is a certain functional unit, and based on assessing environmental parameters or factors it appropriates certain scenario of further actions.

The nature of the association is distinguished by the contractual form (enterprises create associations without the organization of a new entity) and the organization of a joint venture (the emergence of a new entity). Then each of these types will be characterized by its own adaptive management framework.

Fig. 2 presents adapters for managing the association of enterprises with a contractual form. The peculiarity of this model is that companies interact on an equal base, and the hierarchy of adapters is as follows: each of the member companies of the association is influenced by the external environment and develops managerial effects through first-level adapters. The next level is noticed in the interaction of member companies through the adapters of the second level.

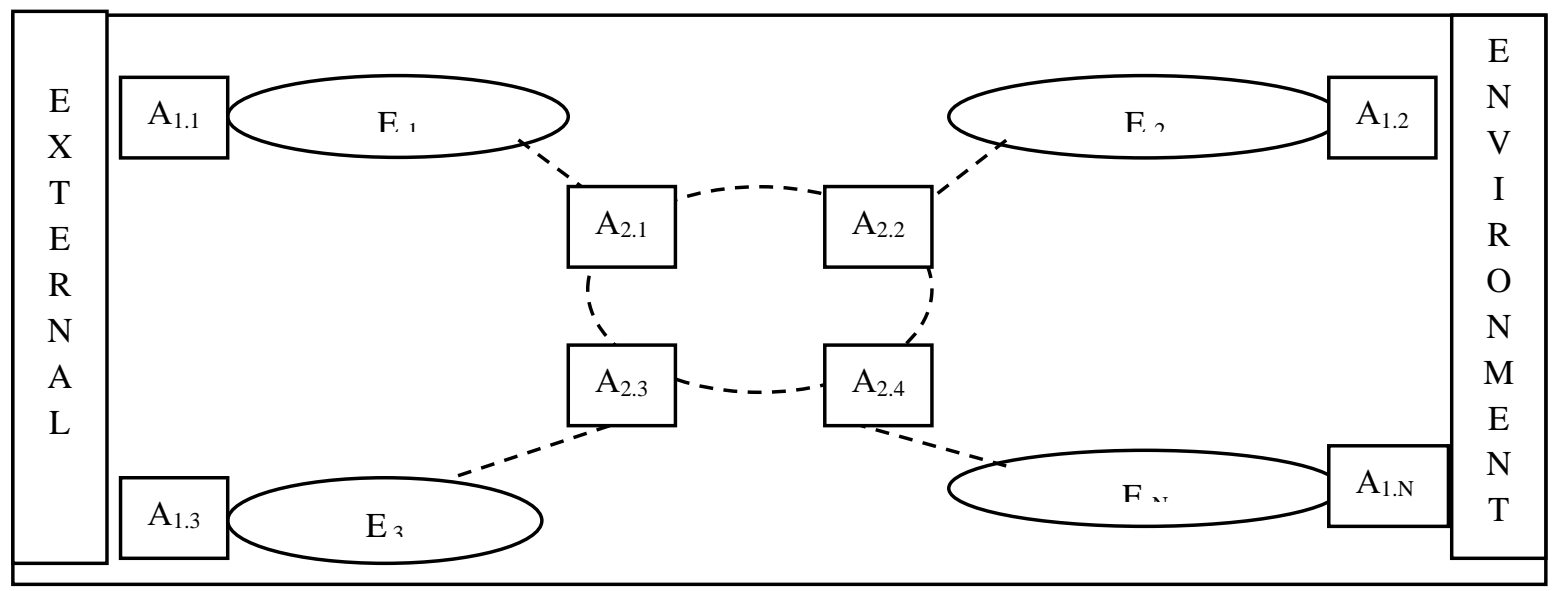

Legend:

$----\quad$ relationships between members of the association;

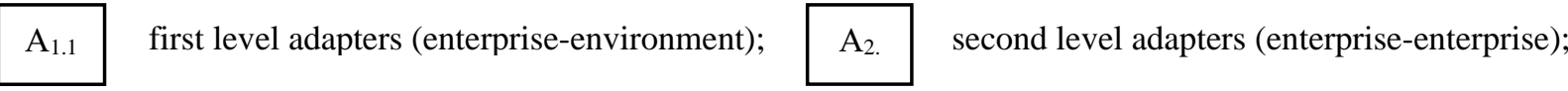

$F_{2} \int$ enterprise, a member of the association;

Fig. 2. Hierarchy of adapters for business associations with a contractual form

Source: designed by the author based on $^{1}$ and ${ }^{2}$

\footnotetext{
1 Чайка, Т. Ю. (2015). Адаптивне управління невизначеністю при прийнятті управлінських рішень. Бізнес Інформ, 2, 286.

${ }^{2}$ Пилипенко, А. А., Литвиненко, А. О. (2016). Потенціал розвитку матеріально-технічної бази підприємства: ідентифікація та оцінювання. Економічний часопис-XXI, 5-6, 52-57.

<http://soskin.info/userfiles/file/EconomicAnnals-pdf/DOI/ea-V159-11.pdf> (2021, лютий, 16).
} 
Another situation is typical for the merger of enterprises with the organization of a joint venture (Fig. 3).

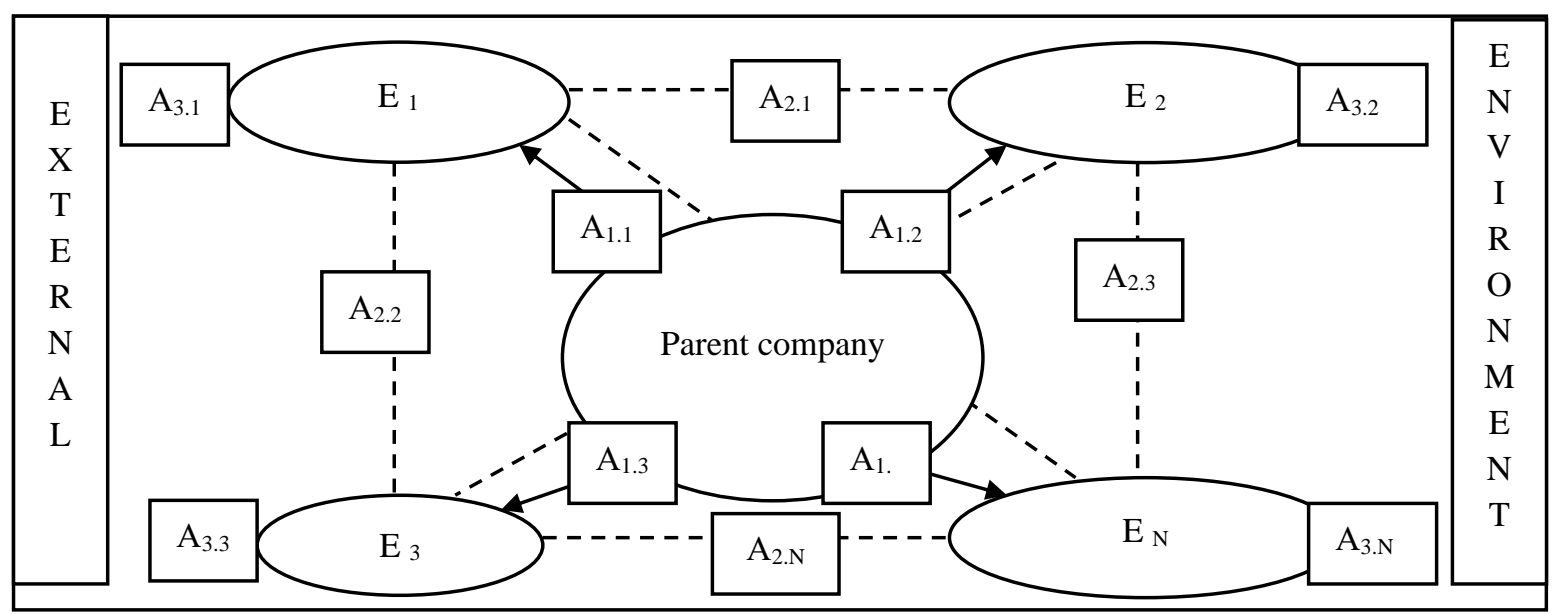

Legend:

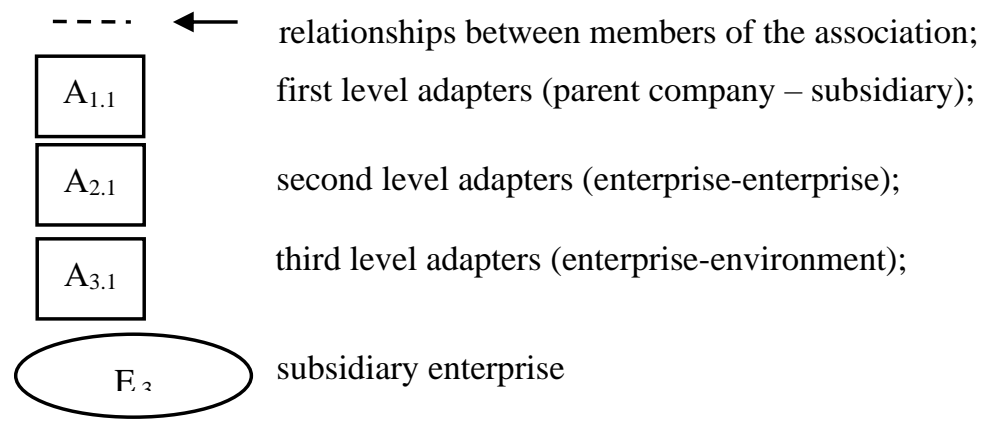

Fig. 3. Hierarchy of adapters for business associations with the organization of a joint venture

\section{Source: designed by the author based on ${ }^{l}$}

The task of the first level adapters is to assess the level and / or changes in the parameters of interaction of the parent company with subsidiaries, second level adapters are needed to develop adaptation scenarios between subsidiaries, while the third level is aimed at assessing environmental parameters. Thus, the adapter is defined as a tool demonstrating the relationship "indicator-management decision", on the basis of which the managerial influence takes place in the association, so it is important to determine whether association has created a new business entity.

Conclusions. Thus, each type of enterprises association is characterized by certain peculiarities of management, which determine certain features of the accounting organization for their business processes. At the same time, unpredictable changes in the economic environment require implementation of new approaches to the organization of activities aimed at maintaining the ability to withstand the negative effects of change, which, in turn, implies the need to focus on the needs of adaptive management. In order to obtain the necessary accounting and analytical information in the process of making management decisions within a certain adaptive management framework, it is proposed to form an appropriate accounting and analytical support for adaptive management of business associations.

\footnotetext{
1 Чайка, Т. Ю. (2015). Адаптивне управління невизначеністю при прийнятті управлінських рішень. Бізнесінформ, 2, 283-288, 286; Пилипенко, А. А., Литвиненко, А. О. (2016). Потенціал розвитку матеріальнотехнічної бази підприємства: ідентифікація та оцінювання. Економічний часопис-XXI, 5-6, 52-57. <http://soskin.info/userfiles/file/EconomicAnnals-pdf/DOI/ea-V159-11.pdf> (2021, лютий, 16).
} 


\section{References:}

1. Chaika, T. Yu. (2015). Adaptyvne upravlinnia nevyznachenistiu pry pryiniatti upravlinskykh rishen [Adaptive management of uncertainty in making management decisions]. BiznesInform [BusinessInform], 2, 283-288. [in Ukrainian].

2. Chalyi, S. C., Levykin, I. V. (2016). Metod adaptyvnoho protsesnoho upravlinnia na osnovi pretsedentnoho pidkhodu [Method of adaptive process control based on a precedent approach]. Naukoiemni tekhnolohii [Science-intensive technologies] , 4 (32), 410-413. [in Ukrainian].

3. Demianenko, T. I. (2012). Otsinka rivnia adaptyvnoi hnuchkosti u formuvanni adaptyvnoho upravlinnia innovatsiino-investytsiinym rozvytkom pidpryiemstva [Assessment of the level of adaptive flexibility in the formation of adaptive management of innovation and investment development of the enterprise]. BiznesInform [BusinessInform], 12, 217-220. [in Ukrainian].

4. Fesik, L. I. (2016). Adaptyvne upravlinnia: evoliutsiia poniattia ta sutnisna kharaketrystyka [Adaptive control: the evolution of the concept and essential characteristics]

$<$ http://umo.edu.ua/images/content/nashi_vydanya/metod_upr_osvit/v_5/29.pdf > (2021, February, 16). [in Ukrainian].

5. Oliinyk, T. V. (2014). Adaptyvni stratehii finansovoho upravlinnia na pidpryiemstvi [Adaptive strategies of financial management at the enterprise]. BiznesInform [BusinessInform], 10, 255-259. [in Ukrainian].

6. Otenko, V. I. (2010). Stratehichnyi vybir pidpryiemstva ta yoho realizatsiia [Strategic choice of the enterprise and its realization]. Kharkiv: INZhEK. [in Ukrainian].

7. Pylypenko, A. A., Lytvynenko, A. O. (2016). Potentsial rozvytku materialno-tekhnichnoi bazy pidpryiemstva: identyfikatsiia ta otsiniuvannia [The potential of the material and technical base of the enterprise: identification and evaluation]. Ekonomichnyi chasopys-XXI [Economic Journal-XXI], 5-6, 52-57.

$<$ http://soskin.info/userfiles/file/EconomicAnnals-pdf/DOI/ea-V159-11.pdf>(2021, february, 16) [in Ukrainian].

8. Senge, P. (1999). Pjataja disciplina: Iskusstvo i praktika samoobuchajushhejsja organizacii [Fifth discipline: The art and practice of self-learning organization]. Moscow: Olimpbiznes. [in Russian].

9. Strokovych, H. V. (2013). Adaptyvnist yak osnova dovhostrokovoho funktsionuvannia pidpryiemstva [Adaptability as a basis for long-term operation of the enterprise] <http://dspace.nua.kharkov.ua/jspui/b itstream/ $123456789 / 36$ 8/1/\%D0\%A1\%D1\%82\%D1\%80\%D0\%BE\%D0\%BA\%D0\%BE\%D0\%B2\%D0\%B8\%D1\%87\% 20\%D0\%93.\%D0\%92..pdf >(2021, February, 16). [in Ukrainian].

10. Styvenson, V. Dzh. (2002). Upravlenie proizvodstvom [Production Management]. Moscow: Binom; Laboratory of Basic Knowledge. [in Russian].

11.Zub, A. T., Laktionov, M. V. (2001). Sistemnyj strategicheskij menedzhment: metodologija i praktika [System strategic management: methodology and practice]. Moscow: Genesis. [in Russian]. 